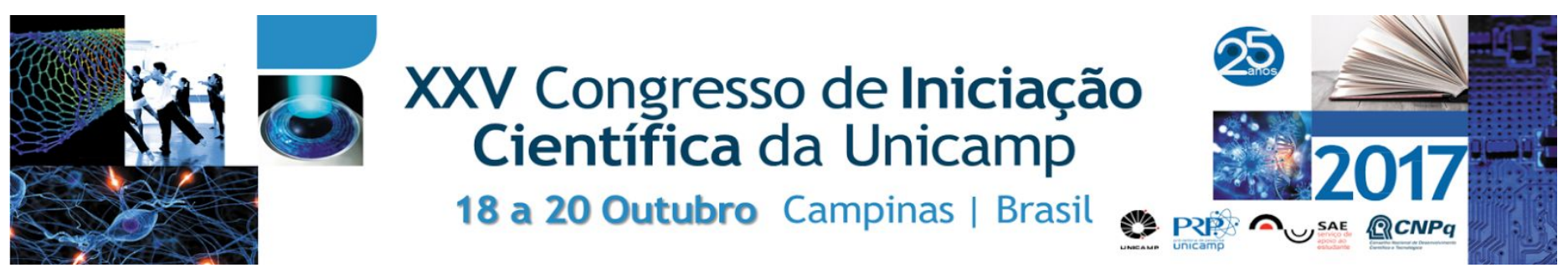

\title{
Quando práticas esportivas são proibidas para mulheres: uma análise de revistas especializadas entre 1941 e 1979
}

\section{Gabriela Feltran Ferreira*, Helena Altmann.}

\section{Resumo}

A inserção da mulher no esporte foi restringida por leis e preconceitos. Decretos-lei foram implantados para determinar quais modalidades poderiam ser praticadas. Assim, o objetivo deste trabalho foi analisar como as revistas especializadas em educação física retratavam essa prática esportiva entres as décadas de 1940-1970, analisando as matérias publicadas sobre mulheres. O estudo foi realizado tomando como fontes edições de revistas especializadas em educação física.

\section{Palavras-chave:}

Mulheres, esporte, visibilidade.

\section{Introdução}

A inserção da mulher no esporte no Brasil, se dá em meados do século XIX (GOELLNER, 2008). Porém, a sua prática foi restringida por leis e preconceitos (REIS, 2006). Em 1941, o decreto-lei $n^{\circ} 3.199$ foi implementado, afirmando no seu Artigo 54 que: "Às mulheres não se permitirá a prática de desportos incompatíveis com as condições de sua natureza." (BRASIL, Lei 3.199, 1941, art.54). No ano de 1965, a deliberação $n .7$ foi implantada afirmando não ser permitida a prática de lutas, futebol, halterofilismo, pólo aquático, rugby e beisebol, pelas mulheres (BRASIL, 1965).

Assim, o objetivo deste trabalho foi analisar como revistas especializadas em educação física retrataram a prática esportiva por mulheres entre 1941 e 1979. Foram analisadas as matérias publicadas sobre mulheres analisando quais modalidades esportivas estão presentes, como é divulgada essa prática, como as mulheres são representadas, entre outros aspectos.

Este estudo, foi realizado tomando como fontes edições de quatro revistas especializadas em educação física situadas nas décadas de 1940 à 1970. Após a consulta, os artigos selecionados foram separadas em 5 categorias: beleza, saúde, cuidados do lar, esportes e diversos.

\section{Resultados e Discussão}

Dentre as 4 revistas consultadas, a Revista Educação Physica se mostrou o periódico com mais publicações voltadas ao público feminino, sendo então destinada tanto para o público masculino, quanto ao feminino. Este fato também se evidência pela linguagem utilizada nesses artigos ser mais informal e próxima ao cotidiano das mulheres.

A categoria beleza se classificou como a mais vasta em número de artigos (44), mostrando que o cuidado e conservação da beleza era uma preocupação com a manutenção da feminilidade e em consequência o padrão heteronormativo imposto pela sociedade (SILVEIRA; VAZ, 2014). A beleza era também sinônimo de saúde, mesmo que a obtenção da bela estética acabasse se sobrepondo ao verdadeiro estilo de vida saudável. A saúde se mostra então um meio para a obtenção da beleza e a manutenção do corpo esbelto. Nesse quesito se evidencia a prática de esportes, que se mostrava um meio de se adquiri-la, mas com suas limitações. Para mulheres era recomendada a livre prática de: natação, tênis, vôlei, basquete (com regras adaptadas), dança, patinação, esgrima com florete. Alguns somente eram recomendados se a mulher possuísse 0 biótipo para tal e com o devido acompanhamento profissional, como o remo e o ciclismo em competição, e o atletismo. Outros, por serem considerados muitos violentos (qualidade do masculino) e que causariam danos aos órgãos femininos, eram abolidos (futebol, lutas, handebol, musculação), buscando também preservar a feminilidade no um campo de modalidades consideradas masculinas (GOELLNER, 2005).

\section{Conclusões}

Dessa forma, a mulher se inseriu no esporte de forma limitada e com inúmeras restrições, com avanços e retrocessos. A beleza da mulher se situava em primeiro plano, sendo construída e mantida através da prática esportiva, mas sobrepondo-se a manutenção de sua feminilidade.

\section{Agradecimentos}

Instituição de formemento: CNPq

BRASIL. Conselho Nacional de Desportos. Deliberação n. 7, de agosto de 1965. Baixa instruções às entidades desportivas do país sobre a prática de desporto pelas mulheres. Disponível em: $<$ http://novo.cev.org.br/biblioteca/deliberacao-n-7-2-agosto-1965/>. Acesso em: 2 abril 2016.

BRASIL. Decreto-lei n. 3199, de 14 de abril de 1941. Estabelece as bases de organização dos desportos em todo o país. 1941. Disponível em: $<$ http://www.planalto.gov.br $>$. Acesso em: 2 abril 2016.

GOELLNER, Silvana Vilodre. Mulher e esporte no Brasil: entre incentivos e interdições elas fazem história. Pensar a prática, v.8, n. 1, p.85-100, 2008. GOELLNER, Silvana Vilodre. Mulheres e futebol no Brasil: entre sombras e visibilidades. Rev. Bras. Educ. Fís. Esp., São Paulo, v. 19, n. 2, p.143-151, abr./jun. 2005 